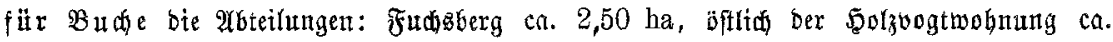
10,0 ha, im NO ca. 0,50 ha, flettes 50 lz cr. 12,0 ha, im ganzen 25,0 ha.

Die vierjährige Sïltigfeitobaner beginnt am 1. Sftober 1926. -

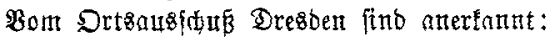

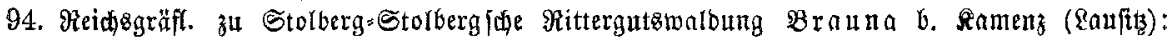
fit $\mathfrak{x}$ Siefer 352,80 ha.

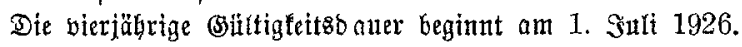

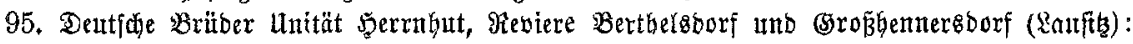

a) für $\mathfrak{g}$ öhanfiefer

b) für Söbenfichte 181,05 ha

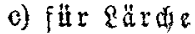

Die vierjäbrige ojilltiglettabauer beginnt am 1 . Dltober 1926.

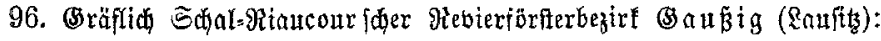

fïr Riefer unb Söbentiefer $=120,18$ ha.

Die vierjäbrige (silttigfeitboner beginnt ant 1. Dltober 1926.

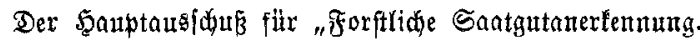

\title{
Warnungl
}

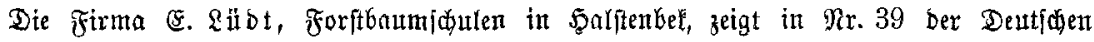

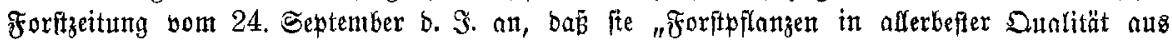
anerfnnntem Saatgut gezogen" liefert. (E. Silbt ift beim beften Biflen nifft in ber lage,

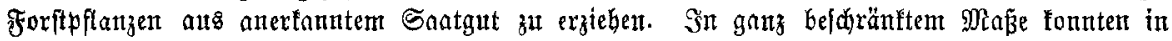

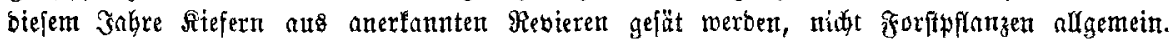

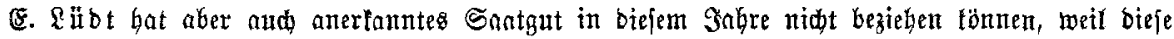
Firma zan Betrieb mit anerfanntem Gratgut nidt zugelaffen ift und iagr baher nad ber

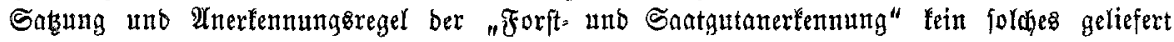
werben barf.

Botgban, ben 16. Sftober 1926 .

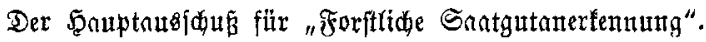
geq. $\operatorname{Ranald}$.

\section{Eolztechnif́um Plau.}

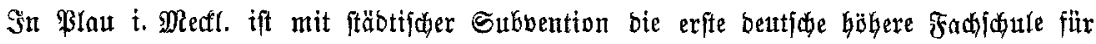

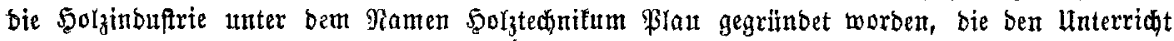

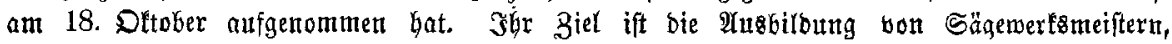

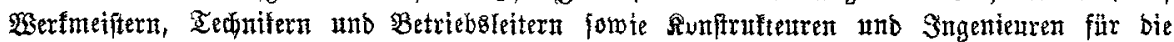

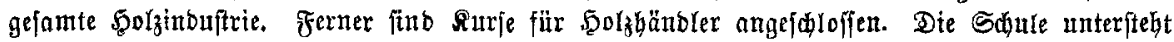

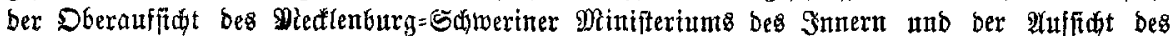

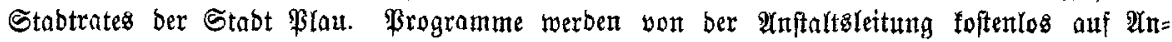
forbern verfantst.

\section{Afadentifhe $\mathfrak{H a d h t h}_{\text {t. }}$}

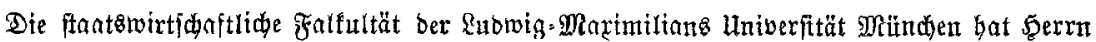

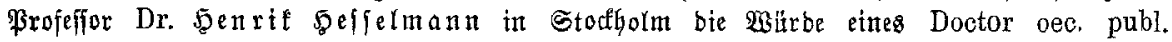
honoris causa verlieken. 